\title{
Structure of Co(II) Species Formed on the Surface of $\gamma$-Alumina Upon Interfacial Deposition
}

\author{
John Vakros ${ }^{1}$, Kyriakos Bourikas ${ }^{2}$, Christos Kordulis ${ }^{1,3}$ and Alexis Lycourghiotis ${ }^{*}, 1$ \\ ${ }^{1}$ Department of Chemistry, University of Patras, GR 265 00, Patras, Greece \\ ${ }^{2}$ School of Science and Technology, Hellenic Open University, Tsamadou 13-15, GR-26222, Patras, Greece \\ ${ }^{3}$ Institute of Chemical Engineering Sciences (FORTH/ICE-HT), P.O. Box 1414, GR-26504, Patras, Greece
}

\begin{abstract}
The mode of retention of $\mathrm{Co}\left(\mathrm{H}_{2} \mathrm{O}\right)_{6}{ }^{2+}$ species at the " $\gamma$-alumina/aquatic solution" interface is refined using simulations, adsorption isotherm, potentiometric mass titrations and mainly proton - ion titrations jointly with diffuse reflectance spectroscopy. It was found that the increase in the Co(II) surface concentration affects considerably the kind of the Co(II) species deposited. Mononuclear/mono-substituted inner sphere Co(II) complexes are formed at extremely low $\mathrm{Co}$ (II) surface concentration. A mixed surface state involving mononuclear/mono-substituted and binuclear/bi-substituted $\mathrm{Co}$ (II) complexes is formed at relatively low Co(II) surface concentration. Only binuclear/bi-substituted Co(II) complexes are formed at intermediate Co(II) surface concentration. Finally, oligo-nuclear inner sphere Co(II) species are formed at relatively high $\mathrm{Co}(\mathrm{II})$ surface concentration, in addition to the bi-nuclear ones. The above species concern a range of surface $\mathrm{Co}(\mathrm{II})$ concentration extending from zero to 2.7 theoretical surface layers of $\left[\mathrm{Co}\left(\mathrm{H}_{2} \mathrm{O}\right)_{6}\right]^{2+}$. The formation of Co(II) surface precipitate starts above these theoretical surface layers. The above indicates that one may control the surface $\mathrm{Co}$ (II) concentration, by adjusting the $\mathrm{Co}$ (II) concentration in the impregnating solution, and thus the $\mathrm{Co}$ (II) surface species formed. This control allows tailoring the preparation of cobalt catalysts supported on $\gamma$-alumina and thus the development of effective $\mathrm{Co} / \gamma$-alumina catalysts.
\end{abstract}

Keywords: Adsorption, cobalt supported on $\gamma$-alumina catalysts, diffuse reflectance spectroscopy, interfacial deposition, preparation of supported catalysts.

\section{INTRODUCTION}

It is well known that cobalt catalysts are important for several industrial applications (e.g. low temperature FischerTropsch synthesis or dry reforming of methane [1-13]). The catalytic activity of these catalysts is strongly related with the characteristics of Co phase, and thus with the preparation method, mainly with the impregnation-deposition procedure followed [14]. In this context the application of equilibrium deposition filtration technique, otherwise called equilibrium adsorption, results to catalysts with high dispersion of the active phase and high performance [14-17]. In the frame of this technique the knowledge of species of the active element deposited on the surface and the concomitant preparative control of these species is of paramount importance [14].

Concerning $\gamma$-alumina, macroscopic studies, carried out in the context of catalyst preparation, have shown that the $\mathrm{Co}$ (II) sorption is $\mathrm{pH}$ dependent and not affected by the ionic strength of the solution [18-21]. Moreover, molecular scale investigation, based on adsorption kinetics and diffuse reflectance spectroscopy $[22,23]$, indicated that $\mathrm{Co}$ (II) forms interfacial mono- or bi-dentate inner sphere complexes at low surface coverage and surface precipitate at high surface

*Address correspondence to this author at the Department of Chemistry, University of Patras, GR 265 00, Patras, Greece;

Tel: +302610367527, +302610367539; Fax: +302610367528;

E-mail: alycour@upatras.gr coverage. The kinetics of adsorption of the Co(II) species on the $\gamma$-alumina surface is described by the following expression $\mathrm{r}_{\mathrm{Co} \text {,bulk }}=k^{\prime} \mathrm{C}^{2}$ Co,bulk [23]. This indicates that two $\mathrm{Co}\left(\mathrm{H}_{2} \mathrm{O}\right)_{6}{ }^{2+}$ ions are involved, from the side of the interface, in the reaction with the reception sites present on the surface of the adsorbent-carrier. It is quite probable that the adsorption step involves the simultaneous adsorption and dimerization of two interfacial $\mathrm{Co}\left(\mathrm{H}_{2} \mathrm{O}\right)_{6}{ }^{2+}$ ions through (hydr)oxo-bridges.

In the present study we refine the mechanism of retention of $\mathrm{Co}(\mathrm{II})$ species at the " $\gamma$-alumina/aquatic solution" interface using, mainly, proton - ion titrations and diffuse reflectance spectroscopy. Specifically, we follow the evolution of the various $\mathrm{Co}$ (II) species formed at the interface as the surface concentration of the Co(II) increases. The study is part of the entire efforts of our group to rationalize the method of preparation of supported catalysts and shift catalyst preparation from the art to the science [24-32].

\section{EXPERIMENTAL}

\section{Substances - Materials}

Cobalt nitrate $\left(\mathrm{Co}\left(\mathrm{NO}_{3}\right)_{2} 6 \mathrm{H}_{2} \mathrm{O}\right.$, Merck, analytical grade) has been used for the preparation of the solutions used in the adsorption experiments. Sodium nitrate stock solutions, used as indifferent electrolyte for regulating the ionic strength, were prepared from the respective solid (Merck analytical 
grade). The indifferent electrolyte is defined as an electrolyte the ions of which are not "specifically" adsorbed on the support surface. These are simply accumulated electrostatically in the outer Helmholtz plane or in the diffused part of the interfacial region developed between the surface of the support particles and the impregnating solution.

$\gamma$-Alumina powder, 90-150 $\mu \mathrm{m}$ was obtained by crushing $\gamma$-alumina extrudates (AKZO, product code Drum 1696, SSA $270 \mathrm{~m}^{2} \mathrm{~g}^{-1}$, water pore volume $0.75 \mathrm{~cm}^{3} \mathrm{~g}^{-1}$ ).

\section{Proton - Ion Titrations}

The Proton - Ion titrations [33] were performed at $25.0 \pm 0.1^{\circ} \mathrm{C}$, ionic strength equal to $0.1 \mathrm{M}$ (adjusted by adding sodium nitrate), and $\mathrm{pH}$ equal to 7.0. A doublewalled, water-jacketed covered vessel equipped with a $\mathrm{pH}$ control system involving a glass saturated calomel electrode (Metrohm) and a dosimat has been used. The aforementioned $\mathrm{pH}$ control system allowed the automatic adjustment of $\mathrm{pH}$ at the desired value $(\mathrm{pH}=7)$ during the adsorption experiments by adding to the "adsorption vessel" $\mathrm{NaOH}$ aqueous solution. Nitrogen gas was passed into the vessel during the adsorption experiments to prevent the dilution of the atmospheric $\mathrm{CO}_{2}$, which would bring about a change in the $\mathrm{pH}$. In each experiment small amounts of cobalt nitrate solution were added into a suspension $(150 \mathrm{~mL})$ containing a sodium nitrate solution and $3.0 \mathrm{~g}$ of $\gamma-\mathrm{Al}_{2} \mathrm{O}_{3}$. The adsorption of $\mathrm{Co}(\mathrm{II})$ species proceeds upon the equilibration of the suspension. As the adsorption process caused a decrease in $\mathrm{pH}$, the $\mathrm{pH}$ control system fed the suspension with the suitable amount of the $\mathrm{NaOH}$ solution to keep $\mathrm{pH}$ at the value of 7 . This amount was recorded for each addition time. A suspension sample equal to $1 \mathrm{~mL}$ was taken at various times during the experiment in order to determine the amount of cobalt absorbed. The $\mathrm{Co}$ (II) concentration was determined photometrically using the Nitrosol R-Salz procedure [34].

\section{Diffuse Reflectance Spectroscopy}

The diffuse reflectance spectra of the solid samples, obtained after adsorption experiments, were recorded in the range $350-800 \mathrm{~nm}$ at room temperature using a UV-vis spectrophotometer (Varian Cary3) equipped with an integration sphere. In all cases, the DR spectra were collected on wet samples (just after equilibration of the suspension and filtration). $\gamma$-alumina impregnated with pure water was used as reference. The powder samples were mounted in a quartz cell, which provided a sample thickness $>3 \mathrm{~mm}$ to guarantee the "infinite" sample thickness. The Microcal Origin, version 5.0, software was used for the spectral deconvolution. Full details for the preparation of the wet samples have been reported elsewhere [22].

\section{Potentiometric Mass Titrations}

Potentiometric mass titrations [35, 36] were performed, under a $\mathrm{N}_{2}$ atmosphere and temperature $\left(25.0 \pm 0.1{ }^{\circ} \mathrm{C}\right)$, for a blank solution $(0.025 \mathrm{M} \mathrm{Co}(\mathrm{II})$, at constant ionic strength $\left(0.1 \mathrm{M}\right.$, regulated by $\left.\mathrm{NaNO}_{3}\right)$ and a suspension of $3.0 \mathrm{~g}$ $\mathrm{Al}_{2} \mathrm{O}_{3}$. The suspension was equilibrated for $20 \mathrm{~h}$ in order to reach an equilibrium $\mathrm{pH}$ value. A small amount of an acid,
$1 \mathrm{M} \mathrm{HNO}_{3}$, was then added to protonate almost all the surface sites, and then, the suspension was titrated by adding small volumes of a $0.1 \mathrm{M} \mathrm{NaOH}$ aqueous solution. The $\mathrm{pH}$ value was recorded after each addition of the basic solution as a function of its volume. A similar titrating procedure was followed for the blank solution.

\section{Adsorption Isotherm Experiments}

The adsorption isotherm experiments were performed at $25.0 \pm 0.1{ }^{\circ} \mathrm{C}$, ionic strength $0.1 \mathrm{M}$ (regulated by sodium nitrate), and $\mathrm{pH}=7.0$ at the same apparatus described in proton - ions experiments. In each experiment a volume of $150 \mathrm{~mL}$ of cobalt nitrate solution of a given $\mathrm{Co}$ (II) concentration, varying in the range 0.0005 to $0.025 \mathrm{M}$, was added into the adsorption vessel. The initial $\mathrm{pH}$ of the cobalt nitrate solutions $(5-5.5)$ was regulated at $\mathrm{pH} 7.0$, before $0.3 \mathrm{~g}$ of $\gamma$-alumina powder added into the stirred solution. As the adsorption process caused a decrease in $\mathrm{pH}$, the $\mathrm{pH}$ control system fed the suspension with the suitable amount of the $\mathrm{NaOH}$ solution to keep $\mathrm{pH}$ at the value of 7 . This amount was recorded for each addition time. The appearance of the plateau indicated that the adsorption process had been practically finished. It is remarkable to note that the higher the initial $\mathrm{Co}$ (II) concentration in the impregnating solution the larger the time required to be obtained a plateau in the curve "amount of the added base solution vs time". The $\mathrm{Co}$ (II) concentration of the impregnating solution was determined photometrically before and after adsorption. The determination was based on the Nitrosol R-Salz procedure [34]. The surface $\mathrm{Co}(\mathrm{II})$ concentration, actually the concentration of the supported $\mathrm{Co}$ (II) (expressed as micromoles of $\mathrm{Co}$ (II) per square meter of the support surface area) was calculated from the above determined $\mathrm{Co}$ (II) concentrations and taking into account the initial $\mathrm{Co}$ (II) concentration in the impregnating solution, the specific surface area and the mass of the support in the sample.

\section{Simulations}

Simulations for obtaining Co(II) solution speciation were carried out using Visual MINTEQ, a computer code for calculating chemical equilibriums in aqueous media [37].

\section{RESULTS AND DISCUSSION}

\section{Co(II)-Species in Aqueous (Nitrate) Solutions}

Several Co(II) species are present in the aqueous solutions, such as the following:

$$
\begin{gathered}
{\left[\mathrm{Co}\left(\mathrm{H}_{2} \mathrm{O}\right)_{6}\right]^{2+},\left[\mathrm{Co}\left(\mathrm{H}_{2} \mathrm{O}\right)_{5}(\mathrm{OH})\right]^{+},\left[\mathrm{Co}\left(\mathrm{H}_{2} \mathrm{O}\right)_{4}(\mathrm{OH})_{2}\right],} \\
{\left[\mathrm{Co}\left(\mathrm{H}_{2} \mathrm{O}\right)_{3}(\mathrm{OH})_{3}\right]^{-}, \mathrm{Co}(\mathrm{OH})_{2}(\mathrm{~s}),\left[\mathrm{Co}\left(\mathrm{H}_{2} \mathrm{O}\right)_{5}\left(\mathrm{NO}_{3}\right)\right]^{+},} \\
{\left[\mathrm{Co}\left(\mathrm{H}_{2} \mathrm{O}\right)_{4}\left(\mathrm{NO}_{3}\right)_{2}\right] .}
\end{gathered}
$$

Previous investigations have provided the equilibrium constants for the transformations between these species [37]. This allows determining the solution Co(II) speciation under conditions similar to those of the deposition, proton-ion and spectroscopic experiments. The speciation obtained is illustrated in Fig. (1). Inspection of this figure shows that the $\left[\mathrm{Co}\left(\mathrm{H}_{2} \mathrm{O}\right)_{6}\right]^{2+}$ complex predominates in the $\mathrm{pH}$ range 4-7.5 and $\mathrm{Co}$ (II) concentration equal to $10^{-2} \mathrm{M}$. The formation of the precipitate $\mathrm{Co}(\mathrm{OH})_{2}(\mathrm{~s})$ starts at $\mathrm{pH}$ just above 7. Similar 
speciation was obtained at relatively low $\mathrm{Co}$ (II) concentration $\left(10^{-4} \mathrm{M}\right)$. The only difference is that the precipitation starts at $\mathrm{pH}=8.5$. Taking into account the above, we performed our adsorption, proton-ion and spectroscopic experiments at $\mathrm{pH}=7$.

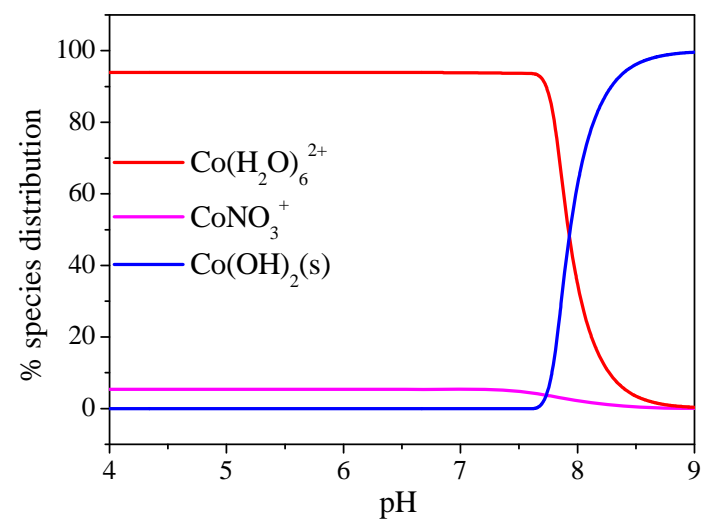

Fig. (1). Speciation of $\mathrm{Co}(\mathrm{II})$ in the $\mathrm{pH}$ range $4-9(0.01 \mathrm{M} \mathrm{Co}(\mathrm{II})$ at $0.1 \mathrm{M}$ ionic strength, regulated by $\mathrm{NaNO}_{3}$ ). The main species present in the solution are indicated. The contribution of the remaining species is negligible under these conditions.

Moreover, taking into account the above speciation we assumed that the only cobalt species present in the solution under our experimental solution is the octahedral $\left[\mathrm{Co}\left(\mathrm{H}_{2} \mathrm{O}\right)_{6}\right]^{2+}$ aqua complex (Fig. 2).

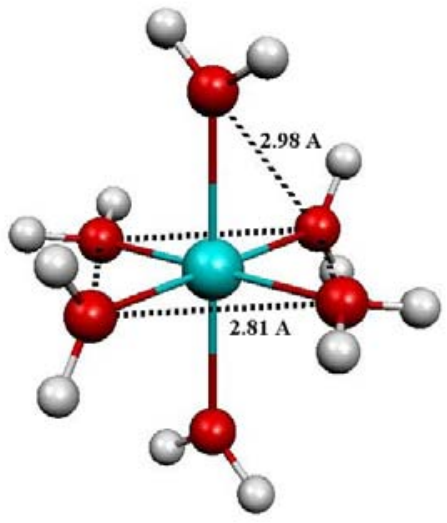

Fig. (2). The structure of the $\left[\mathrm{Co}\left(\mathrm{H}_{2} \mathrm{O}\right)_{6}\right]^{2+}$ ion. (Green ball: cobalt, red balls: oxygen atoms, gray balls: hydrogen atoms).

In order to accomplish the picture for the $\left[\mathrm{Co}\left(\mathrm{H}_{2} \mathrm{O}\right)_{6}\right]^{2+}$ species to be adsorbed it is necessary to focus on the charge distribution over the various atoms. A traditional way to obtain such a distribution is based on the Pauling valence bond. Following this empirical method the charge of this complex $(+2)$ is distributed equally in the water ligands $(+0.33)$ assigning a zero charge above cobalt. We have recently improving this empirical charge distribution by performing ab-initio calculations in the frame of the density functional theory DFT [27]. The results are illustrated in Table 1.
Table 1. Charge distribution in the $\left[\mathrm{Co}\left(\mathrm{H}_{2} \mathrm{O}\right)_{6}\right]^{2+}$ ion obtained by performing ab-initio calculations and different approaches in the frame of the DFT [27].

\begin{tabular}{|c|c|c|c|c|}
\hline \multirow{2}{*}{ Atom } & \multicolumn{4}{|c|}{ Method } \\
\cline { 2 - 5 } & Mulliken & Lowdin & NPA & CHelpG \\
\hline \hline Co & +0.95 & +1.12 & +1.42 & +1.6 \\
\hline $\mathrm{O}$ & -0.56 & -0.30 & -0.96 & -0.93 \\
\hline $\mathrm{H}$ & +0.36 & +0.23 & +0.52 & +0.49 \\
\hline
\end{tabular}

Inspection of Table 1 shows that the adopted approaches result to very different charges above the cobalt atom with respect to the zero one assigned by the aforementioned empirical method. Moreover, the charge distribution depends, more or less, on the particular approach adopted. It seems plausible adopting the mean charge above the $\mathrm{Co}$ atom $(+1.3)$ and then equally distributing the remaining charge $(+0.7)$ in the six aqua ligands $(+0.12)$.

\section{Cobalt Uptake of $\boldsymbol{\gamma}$-Alumina}

Fig. (3) illustrates the variation of the surface density of Co with the Co concentration in the aqueous solution. Both parameters were obtained at equilibrium. Inspection of this figure shows the very high capability of $\gamma$-alumina to adsorb $\mathrm{Co}(\mathrm{II})$ species. In fact, the maximum surface density obtained $\left(36 \mu \mathrm{mol} \mathrm{\textrm {m } ^ { - 2 }}\right.$ ) is much higher than that obtained using titania under similar conditions $\left(7 \mu \mathrm{mol} \mathrm{m}^{-2}\right)$ at $\mathrm{pH}=7.5$ [27]. Moreover, it is important to note that the maximum surface density of Co corresponds to a surface coverage equal to 11 monomolecular layers of the $\left[\mathrm{Co}\left(\mathrm{H}_{2} \mathrm{O}\right)_{6}\right]^{2+}$ ions. This strongly indicates Co deposition through surface (interfacial) precipitation of $\mathrm{Co}$ (II) species, at least for quite high values of Co concentration in the aqueous solution. Another important observation is the $S$ type of the adsorption

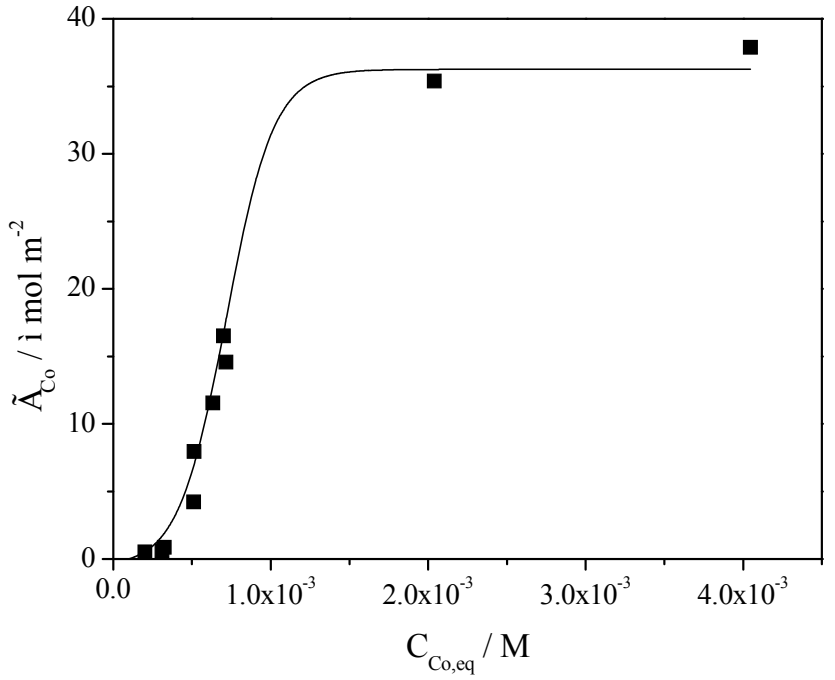

Fig. (3). Variation of the surface Co density, $\Gamma_{\mathrm{Co}} / \mu \mathrm{mol} \mathrm{m}{ }^{-2}$, with the Co concentration in the aqueous solution, $\mathrm{C}_{\mathrm{Co}, \mathrm{eq}} \cdot \mathrm{pH}=7,25^{\circ} \mathrm{C}$, $I=0.1 \mathrm{M}$, volume of impregnating solution $=150 \mathrm{~mL}$ and mass of $\gamma$-alumina $=0.3 \mathrm{~g}[23]$. 
isotherm. This presumably indicates promotion of the adsorption by the cobalt (II) species already adsorbed. We shall return to this point in the next subsection where we present the structure of the deposited $\mathrm{Co}(\mathrm{II})$ species at different surface $\mathrm{Co}(\mathrm{II})$ concentrations.

\section{STRUCTURE OF THE DEPOSITED CO(II) SPECIES AT DIFFERENT SURFACE CO(II) CONCENTRATIONS}

\section{Very Low Surface Concentration of Co(II)}

Fig. (4a) illustrates the amount of the hydrogen ions released from the surface to the solution against the amount of $\left[\mathrm{Co}\left(\mathrm{H}_{2} \mathrm{O}\right)_{6}\right]^{2+}$ ions deposited at the interface. The experimental data were collected in the range of $0-0.018$ theoretical surface layers of $\left[\mathrm{Co}\left(\mathrm{H}_{2} \mathrm{O}\right)_{6}\right]^{2+}$. This corresponds to experimental points below the first and second point of the isotherm (Fig. 3). In this range all the amount of the added $\mathrm{Co}(\mathrm{II})$ is deposited at the interface. Inspection of this figure shows a linear increase of the amount of the hydrogen ions released to the solution with the amount of the $\mathrm{Co}$ (II) deposited at the interface. Let us first explain the origin of this curve. Positive charge is accumulated near the surface
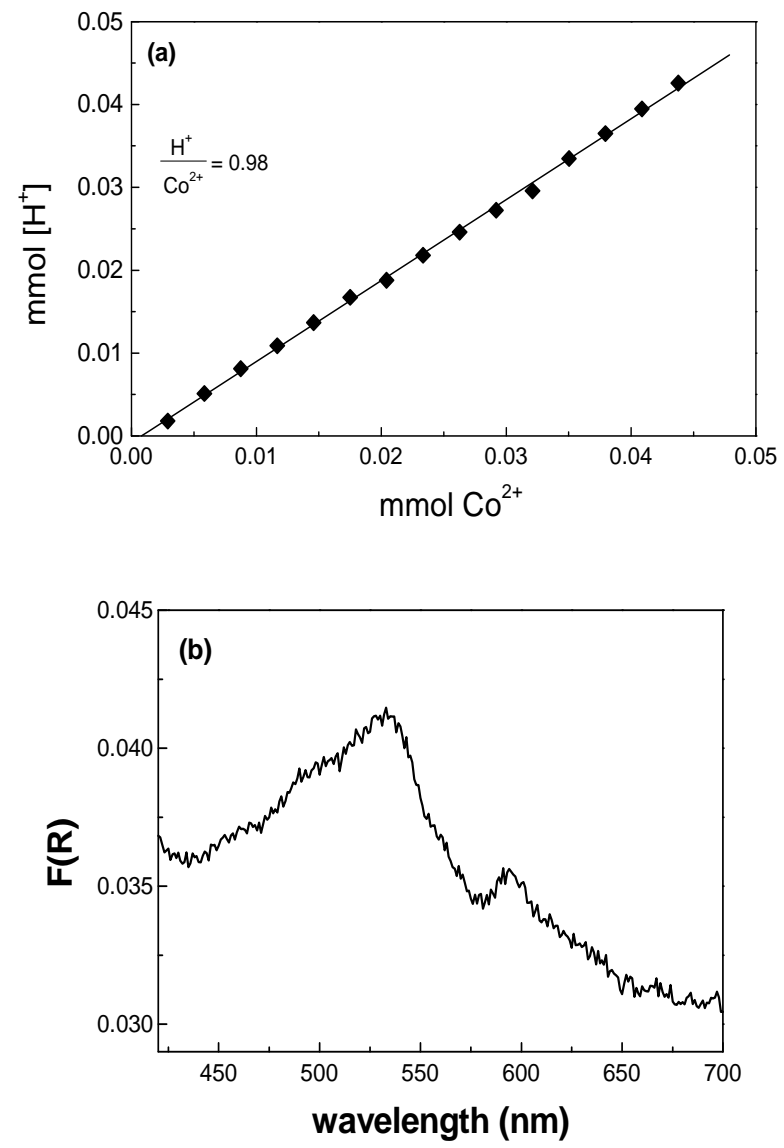

Fig. (4). (a) Proton-ion titration curve obtained for the Co adsorption by $\gamma$-alumina in $0-0.018$ theoretical surface layers of $\left[\mathrm{Co}\left(\mathrm{H}_{2} \mathrm{O}\right)_{6}\right]^{2+}$. The ratio $\left[\mathrm{H}^{+}\right] /\left[\mathrm{Co}^{2+}\right]$ is indicated. (b) Diffuse reflectance spectrum of a sample with a $\mathrm{Co}$ (II) surface concentration equal to 0.006 theoretical surface layers of $\left[\mathrm{Co}\left(\mathrm{H}_{2} \mathrm{O}\right)_{6}\right]^{2+}$. due to the deposition of the $\left[\mathrm{Co}\left(\mathrm{H}_{2} \mathrm{O}\right)_{6}\right]^{2+}$ species. Thus, one may expect the removal of hydrogen ions from one or more of the charged planes of the compact layer of the interface (surface plane, inner or outer Helmholtz plane) [14] and thus the increase of solution hydrogen ions concentration. This removal is necessary in order to compensate the increase of positive charge in the compact layer. Therefore, the linear increase in the amount of the removed hydrogen ions with the $\mathrm{Co}$ (II) surface concentration is rather obvious, provided that the same deposition mechanism is followed within this $\mathrm{Co}(\mathrm{II})$ surface concentration range.

The ratio "amount of the hydrogen ions released/Co(II) deposited", $\left[\mathrm{H}^{+}\right] /\left[\mathrm{Co}^{2+}\right]$, which is obtained from the slope of the above line, is very sensitive to the structure of the $\mathrm{Co}$ (II) species formed at the interface. The value obtained $(0.98)$ is quite large ruling out retention at the interface through electrostatic forces and presumably through hydrogen bonds [14]. This value strongly indicates formation of a mononuclear, mono-substituted inner sphere complex by replacing one water ligand of the $\left[\mathrm{Co}\left(\mathrm{H}_{2} \mathrm{O}\right)_{6}\right]^{2+}$ ion with a surface oxygen of $\gamma$-alumina. The proposed structure is presented in Fig. (5), where the (110) crystal face of $\gamma$-alumina has been used in its hydrated condition, as proposed by Digne et al. $[38,39]$. According to recent literature it has been estimated that this face predominates with $74 \%$ of the total surface area of $\gamma$-alumina [38].

This is corroborated by the charge distribution obtained for the $\left[\mathrm{Co}\left(\mathrm{H}_{2} \mathrm{O}\right)_{6}\right]^{2+}$ ions. In fact, the formation of a coordinative $\mathrm{Co}-\mathrm{O}$ bond with a surface oxygen causes the transfer of a positive charge equal to 1.3 at a distance from the surface slightly larger than that of hydrogen of the surface hydroxyl. This justifies the removal of a slightly lower charge $(+0.98)$, that is the removal of a hydrogen ion. The above argument implies negligible influence of the interface on hydrogen removal, which seems to be quite realistic at $\mathrm{pH}$ 7.0. This $\mathrm{pH}$ value is very close to the point of zero charge of the $\gamma$-alumina used in this study (7.5) where the effect of the interface is minimal.

The formation of a Al-O-Co bridge is also corroborated by the DR spectra obtained for samples with Co(II) surface concentration in the range $0-0.018$ theoretical surface layers of $\left[\mathrm{Co}\left(\mathrm{H}_{2} \mathrm{O}\right)_{6}\right]^{2+}$. A typical example is illustrated in Fig. (4b). Inspection of this spectrum shows one main band at $535 \mathrm{~nm}$, two small shoulders at 460 and $495 \mathrm{~nm}$ and one smaller band at $585 \mathrm{~nm}$. This spectrum is very similar but not identical to the spectrum of the $\left[\mathrm{Co}\left(\mathrm{H}_{2} \mathrm{O}\right)_{6}\right]^{2+}$ ions in the solution [22]. Actually, the spectrum of $\left[\mathrm{Co}\left(\mathrm{H}_{2} \mathrm{O}\right)_{6}\right]^{2+}$ in the range 400-800 nm exhibits one main band at about $524 \mathrm{~nm}$ and two well-defined shoulders at 456 and $625 \mathrm{~nm}$. According to the literature, the following assignments are favoured [22]: ${ }^{4} \mathrm{~T}_{1 \mathrm{~g}} \rightarrow{ }^{4} \mathrm{~T}_{1 \mathrm{~g}}(\mathrm{P})$ at $524 \mathrm{~nm}$ and ${ }^{4} \mathrm{~T}_{1 \mathrm{~g}} \rightarrow{ }^{4} \mathrm{~A}_{2 \mathrm{~g}}$ at $625 \mathrm{~nm}$ with the shoulder on the short-wavelength side being attributed to spin-orbit coupling effects or to transition to doublet states.

The main differences observed in the spectrum of Fig. (4b) were the extension of the absorption to longer wavelengths and the appearance of a band at $585 \mathrm{~nm}$. Exhaustive spectroscopic analysis has shown that these changes indicate formation of inner sphere complexes [22]. In particular, the adsorption at $585 \mathrm{~nm}$ was attributed to the formation of the bridge $\mathrm{Co}-\mathrm{O}-\mathrm{Al}$ [22]. Thus, the joint 


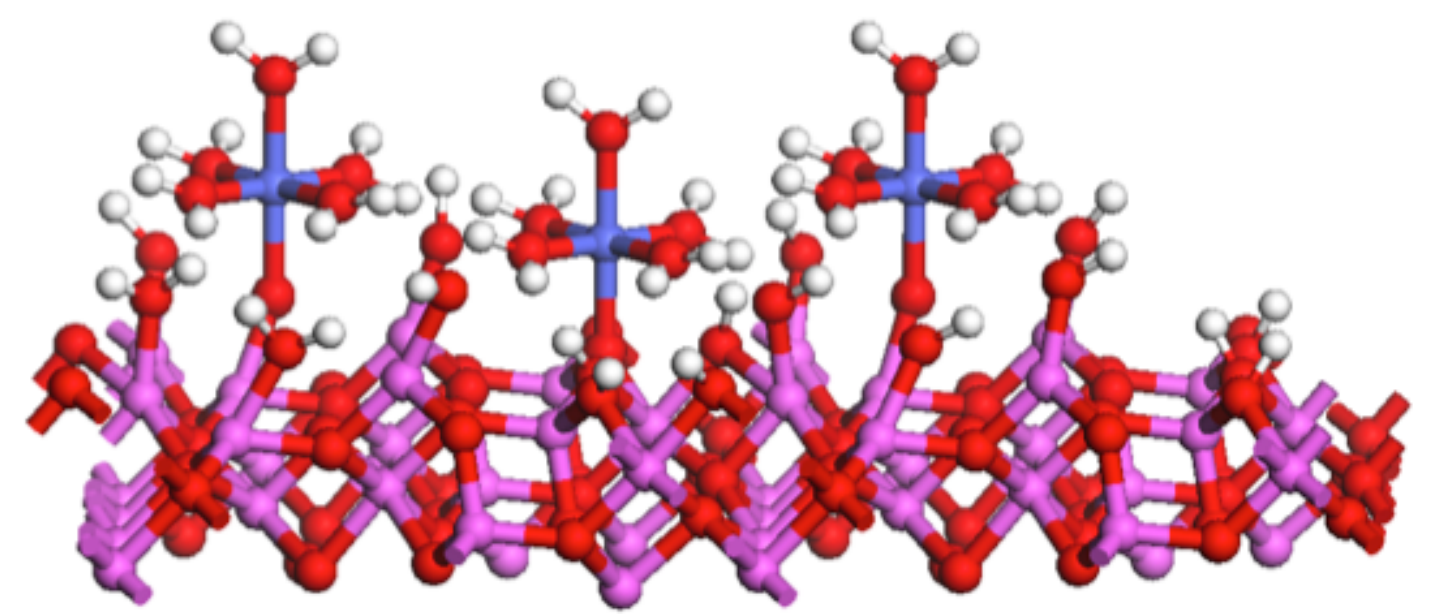

Fig. (5). Schematic representation of the mono-nuclear, mono-substituted inner sphere complex formed upon deposition of the $\left[\mathrm{Co}\left(\mathrm{H}_{2} \mathrm{O}\right)_{6}\right]^{2+}$ ions on the (110) face of $\gamma$-alumina surface, at very low surface concentration of Co $\left(0-0.018\right.$ theoretical surface layers of $\left.\left[\mathrm{Co}\left(\mathrm{H}_{2} \mathrm{O}\right)_{6}\right]^{2+}\right)$. (Purple balls: aluminum atoms, red balls: oxygen atoms, blue balls: cobalt atoms, grey balls: hydrogen atoms).

application of DR spectroscopy and proton-ion titration reveals the formation of a mono-nuclear, mono-substituted inner sphere complex $\left[\mathrm{Co}\left(\mathrm{H}_{2} \mathrm{O}\right)_{5}(\mathrm{OAl})\right]$ at very low $\mathrm{Co}(\mathrm{II})$ surface concentration. The formation of this monosubstituted complex was inferred but not directly resulted by the application only of DRS [22].

\section{Low Surface Concentration of Co(II)}

Fig. (6a) illustrates the proton-ion titration curve in the range of $\mathrm{Co}(\mathrm{II})$ surface concentration 0.018 - 0.150 theoretical surface layers of $\left[\mathrm{Co}\left(\mathrm{H}_{2} \mathrm{O}\right)_{6}\right]^{2+}$. This corresponds to the first and second point of the isotherm of Fig. (3). Again all the amount of the added Co(II) is deposited at the interface.

One may observe that the ratio $\left[\mathrm{H}^{+}\right] /\left[\mathrm{Co}^{2+}\right]$ was increased from 0.98 to 1.26 . On the other hand the deconvolution of a DR spectrum obtained near this range (Fig. 6b) clearly shows the occurrence of five peaks. It seems that these peaks would be classified into two groups. The first three peaks correspond to the main band of $\mathrm{Co}\left(\mathrm{H}_{2} \mathrm{O}\right)_{6}{ }^{2+}$, whereas the other two peaks correspond to the extension of this band to longer wavelength values. The band at $635 \mathrm{~nm}$ can be analyzed into two components, one at $585 \mathrm{~nm}$ and the other at $640 \mathrm{~nm}$. These could be due to the ${ }^{4} \mathrm{~T}_{1 \mathrm{~g}} \rightarrow{ }^{4} \mathrm{~A}_{2 \mathrm{~g}}$ transition corresponding to the exchange of the aqua ligands of the adsorbed $\mathrm{Co}\left(\mathrm{H}_{2} \mathrm{O}\right)_{6}{ }^{2+}$ species by two different ligands. So, the deconvolution peaks at 585 and $640 \mathrm{~nm}$ could be respectively attributed to the exchange of aqua ligands by $\mathrm{Al} x \mathrm{OH} y(x 1,2$, or $3 ; y 0$ or 1$)$ and $\mathrm{Co}-\mathrm{O}-\mathrm{H}$ (i.e., bridging hydroxo) ligands [22].

Therefore, this spectrum indicates formation of binuclear and/or oligo-nuclear inner sphere complexes. By combining the value obtained for aforementioned ratio and the DR spectrum we propose a mixed situation for the species formed at the interface. This is illustrated in Fig. (7).

In fact, the formation of a bi-nuclear, bi-substituted inner sphere complex corresponds to a ratio $\left[\mathrm{H}^{+}\right] /\left[\mathrm{Co}^{2+}\right]=1.50$ (1.0 for the Co-O-Al bridges and 0.5 for the $\mathrm{Co}-\mathrm{O}(\mathrm{H})-\mathrm{Co}$ bridge). Thus, a mixed formation of the aforementioned species is required for predicting the experimentally determined ratio (1.26).


Fig. (6). (a) Proton-ion titration curve obtained for the Co adsorption by $\gamma$-alumina in $0.018-0.150$ theoretical surface layers of $\left[\mathrm{Co}\left(\mathrm{H}_{2} \mathrm{O}\right)_{6}\right]^{2+}$. The ratio $\left[\mathrm{H}^{+}\right] /\left[\mathrm{Co}^{2+}\right]$ is indicated. (b) Diffuse reflectance spectrum of a sample with 0.182 theoretical surface layers of $\left[\mathrm{Co}\left(\mathrm{H}_{2} \mathrm{O}\right)_{6}\right]^{2+}$. 


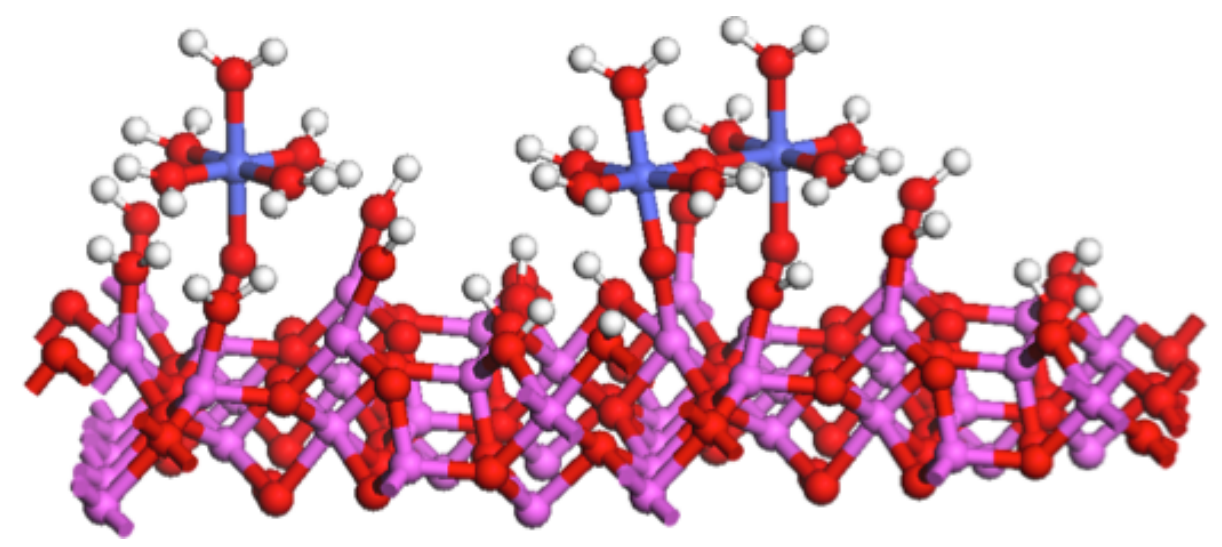

Fig. (7). Schematic representation of mono-nuclear, mono-substituted and bi-nuclear, bi-substituted inner sphere complexes formed upon deposition of the $\left[\mathrm{Co}\left(\mathrm{H}_{2} \mathrm{O}\right)_{6}\right]^{2+}$ ions on the (110) face of $\gamma$-alumina surface, at low surface concentration of Co (0.018-0.150 theoretical surface layers of $\left.\left[\mathrm{Co}\left(\mathrm{H}_{2} \mathrm{O}\right)_{6}\right]^{2+}\right)$. (Purple balls: aluminum atoms, red balls: oxygen atoms, blue balls: cobalt atoms, grey balls: hydrogen atoms).
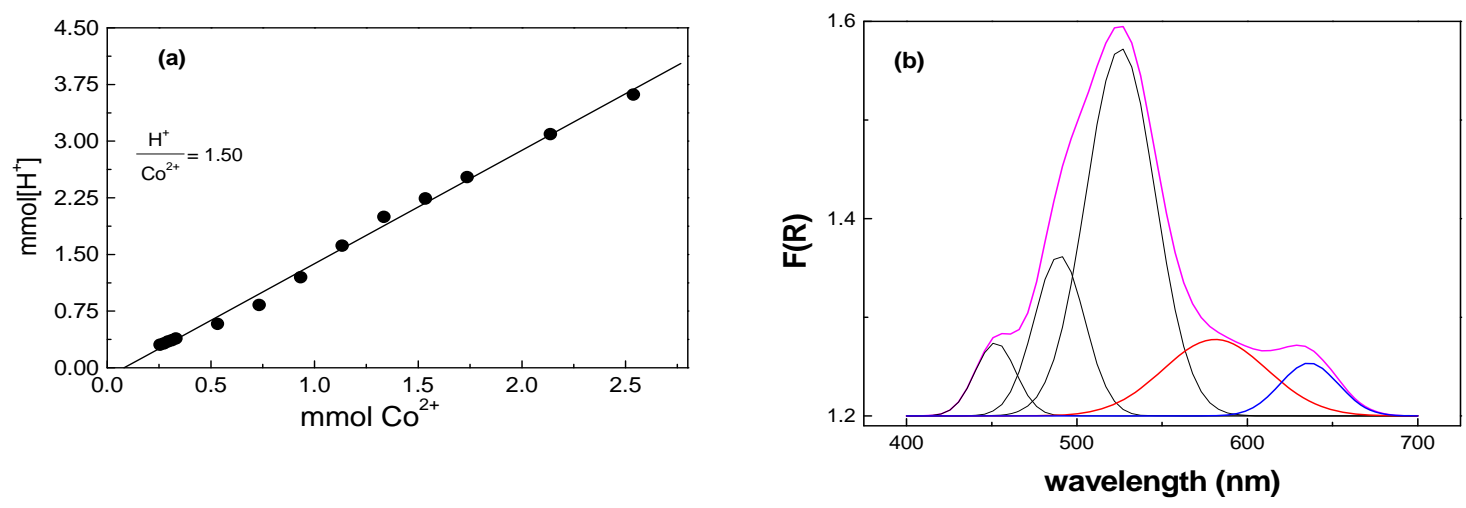

Fig. (8). (a) Proton-ion titration curve obtained for the Co adsorption by $\gamma$-alumina $0.150-1.100$ theoretical surface layers of $\left[\mathrm{Co}\left(\mathrm{H}_{2} \mathrm{O}\right)_{6}\right]^{2+}$. The ratio $\left[\mathrm{H}^{+}\right] /\left[\mathrm{Co}^{2+}\right]$ is indicated. (b) Diffuse reflectance spectrum of a sample with 0.580 theoretical surface layers of $\left[\mathrm{Co}\left(\mathrm{H}_{2} \mathrm{O}\right)_{6}\right]^{2+}$.

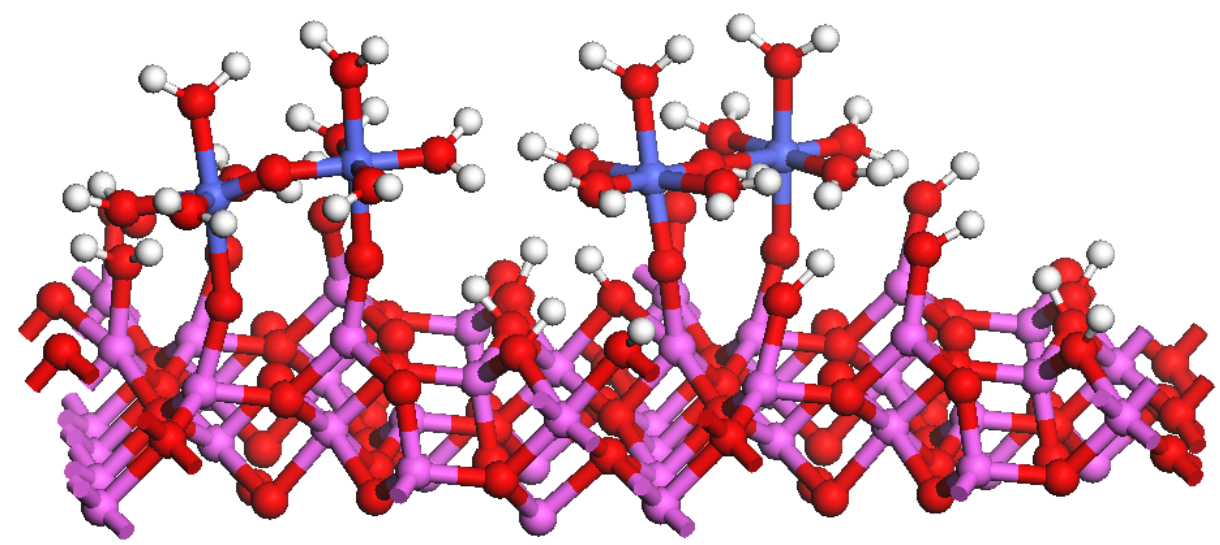

Fig. (9). Schematic representation of bi-nuclear, bi-substituted inner sphere complexes formed upon deposition of the $\left[\mathrm{Co}\left(\mathrm{H}_{2} \mathrm{O}\right)_{6}\right]^{2+}$ ions on the (110) face of $\gamma$-alumina surface, at intermediate surface concentration of Co $\left(0.150-1.100\right.$ theoretical surface layers of $\left.\left[\mathrm{Co}\left(\mathrm{H}_{2} \mathrm{O}\right)_{6}\right]^{2+}\right)$. (Purple balls: aluminum atoms, red balls: oxygen atoms, blue balls: cobalt atoms, grey balls: hydrogen atoms).

\section{Intermediate Surface Concentration of Co(II)}

Fig. (8a) illustrates the proton-ion titration curve in the range of $\mathrm{Co}(\mathrm{II})$ surface concentration $0.150-1.100$ theoretical surface layers of $\left[\mathrm{Co}\left(\mathrm{H}_{2} \mathrm{O}\right)_{6}\right]^{2+}$. This corresponds to a range near to the third point of the isotherm of Fig. (3). Again all the amount of the added Co(II) is deposited at the interface. As already mentioned, the value 1.50 for the ratio
$\left[\mathrm{H}^{+}\right] /\left[\mathrm{Co}^{2+}\right]$ obtained in this surface Co concentration range is compatible with the formation of a bi-nuclear, bisubstituted inner sphere complex (Fig. 9). The DR spectra obtained at intermediate surface $\mathrm{Co}$ (II) concentrations are similar to those illustrated in Fig. (6b) showing the formation of both $\mathrm{Co}-\mathrm{O}-\mathrm{Al}$ and $\mathrm{Co}-\mathrm{O}(\mathrm{H})-\mathrm{Co}$ bridges.

A typical example is illustrated in Fig. (8b). 


\section{Relatively High Surface Concentration of Co(II)}

Fig. (10a) illustrates the proton-ion titration curve in the range of $\mathrm{Co}$ (II) surface concentration 1.10 - 2.70 theoretical surface layers of $\left[\mathrm{Co}\left(\mathrm{H}_{2} \mathrm{O}\right)_{6}\right]^{2+}$. This corresponds to a range near the fourth point of the isotherm of Fig. (3). Even in this case all the amount of the added Co(II) is deposited at the interface. Inspection of Fig. (10a) shows that the ratio $\left[\mathrm{H}^{+}\right] /\left[\mathrm{Co}^{2+}\right]$ is further increased attaining a value equal to 1.82. Moreover, the DR spectra recorded for samples in this Co concentration range (Fig. 10b) show an increase of the band at $640 \mathrm{~nm}$ with respect to the band at $585 \mathrm{~nm}$ (compare Figs. 6b, 8b with Fig. 10b).

Both observations indicate a mixed situation which involves oligonuclear configurations in addition to the binuclear ones (see for example Fig. 11).

\section{Quite High Surface Concentration of Co(II)}

As already mentioned, the $\mathrm{Co}(\mathrm{II})$ surface concentration equal to 2.70 theoretical surface layers of $\left[\mathrm{Co}\left(\mathrm{H}_{2} \mathrm{O}\right)_{6}\right]^{2+}$ corresponds nearly to the third point of the isotherm of Fig. (3). Inspection of this isotherm shows that much more amount of $\mathrm{Co}$ (II) is deposited on the surface under conditions which do not favor solution precipitation (compare Fig. 3 with Fig. 2). This indicates interfacial or surface precipitation of the cobalt phase for surface Co(II) concentration higher than 2.70 theoretical surface layers of $\left[\mathrm{Co}\left(\mathrm{H}_{2} \mathrm{O}\right)_{6}\right]^{2+}$. This is reflected in the increasing formation of the Co-O-Co bonds with respect to the formation of Co-O-Al, manifested by the relatively high absorption at 640 nm (Fig. 12).
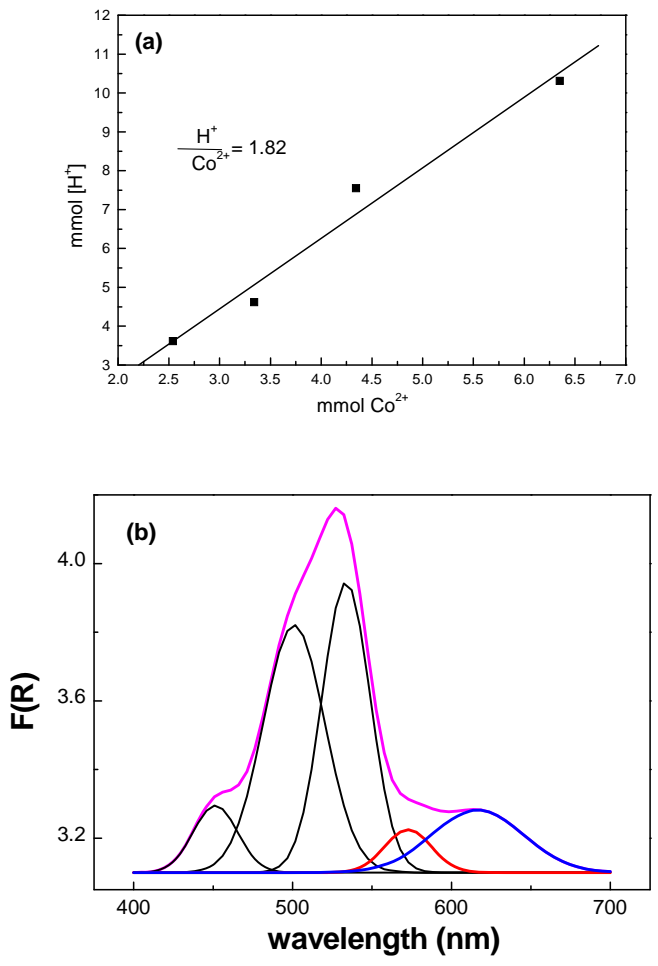

Fig. (10). (a) Proton-ion titration curve obtained for the Co adsorption on the $\gamma$-alumina in $1.10-2.70$ theoretical surface layers of $\left[\mathrm{Co}\left(\mathrm{H}_{2} \mathrm{O}\right)_{6}\right]^{2+}$. The ratio $\left[\mathrm{H}^{+}\right] /\left[\mathrm{Co}^{2+}\right]$ is indicated. (b) Diffuse reflectance spectrum of a sample with 2.50 theoretical surface layers of $\left[\mathrm{Co}\left(\mathrm{H}_{2} \mathrm{O}\right)_{6}\right]^{2+}$.

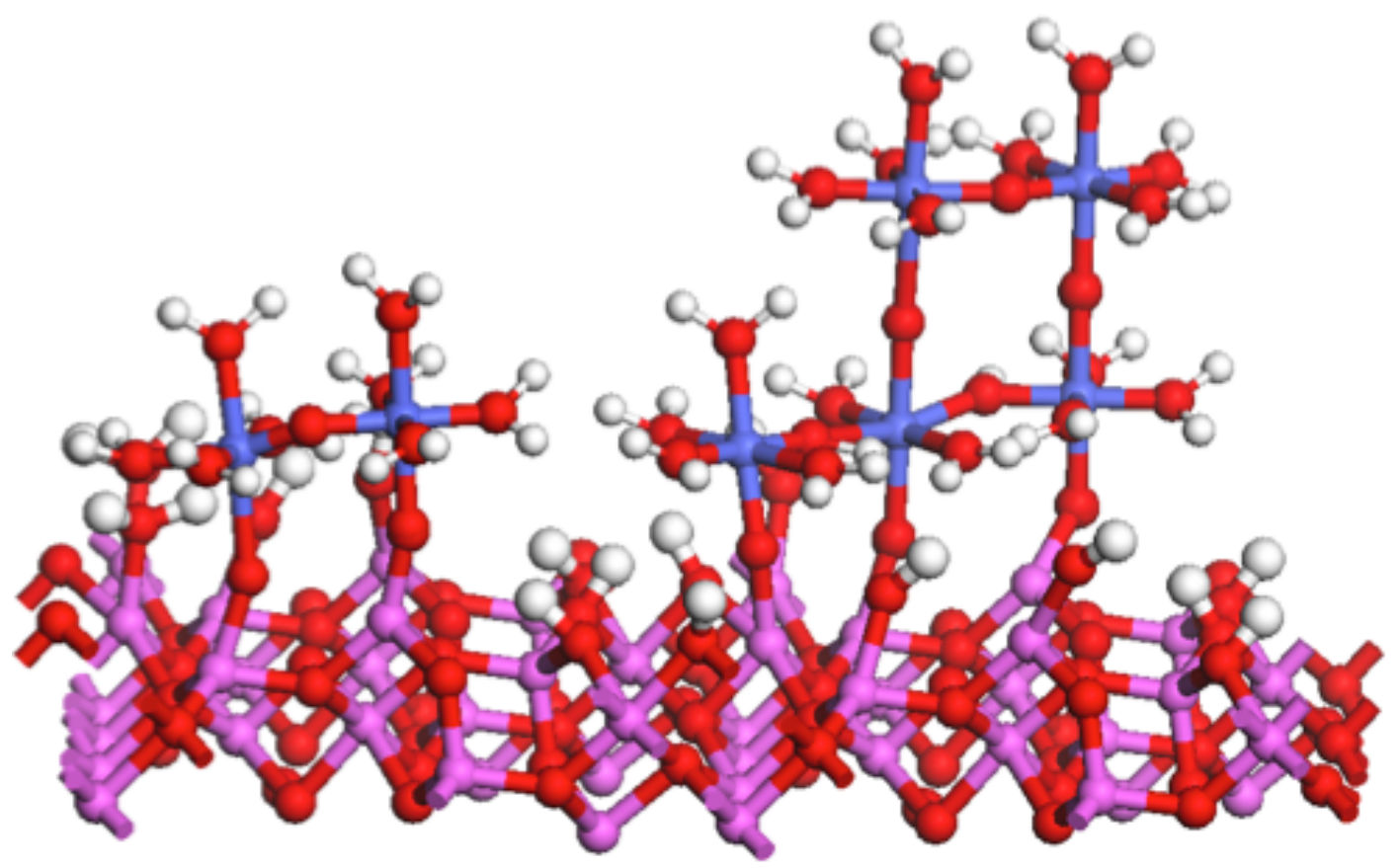

Fig. (11). Schematic representation of bi-nuclear, bi-substituted inner sphere complexes (left) and oligonuclear configurations (right) formed upon deposition of the $\left[\mathrm{Co}\left(\mathrm{H}_{2} \mathrm{O}\right)_{6}\right]^{2+}$ ions on the (110) face of $\gamma$-alumina surface, at relatively high surface concentration of Co $(1.100-2.700$ theoretical surface layers of $\left.\left[\mathrm{Co}\left(\mathrm{H}_{2} \mathrm{O}\right)_{6}\right]^{2+}\right)$. (Purple balls: aluminum atoms, red balls: oxygen atoms, blue balls: cobalt atoms, grey balls: hydrogen atoms). 
Table 2. The various cobalt species formed at the " $\gamma$-alumina/aquatic solution" interface for different values of Co(II) surface concentrations.

\begin{tabular}{|c|c|c|c|}
\hline $\begin{array}{c}\text { Co(II) Surface Density } \\
\left(\boldsymbol{\mu} \mathbf{m o l} \mathbf{C o ~}^{-2}\right)\end{array}$ & $\begin{array}{c}\text { Theoretical Surface } \\
\text { Layers of }\left[\mathbf{C o}\left(\mathbf{H}_{2} \mathbf{O}\right)_{6}\right]^{2+}\end{array}$ & $\frac{\mathbf{H}^{+}}{\mathbf{C o}^{2+}}$ & Local Structure \\
\hline \hline $0-0.06$ & $0-0.018$ & 0.98 & mononuclear/mono-substituted inner sphere Co(II) complexes \\
\hline $0.06-0.50$ & $0.018-0.150$ & 1.26 & mononuclear/mono-substituted and binuclear/bi-substituted inner sphere Co(II) complexes \\
\hline $0.50-3.60$ & $0.150-1.100$ & 1.50 & binuclear/bi-substituted inner sphere Co(II) complexes \\
\hline $3.60-9.00$ & $1.100-2.700$ & 1.82 & Bi-nuclear/bi-substituted and oligo-nuclear inner sphere Co(II) complexes \\
\hline$>9$ & $>2.7$ & $>1.82$ & surface precipitation \\
\hline
\end{tabular}

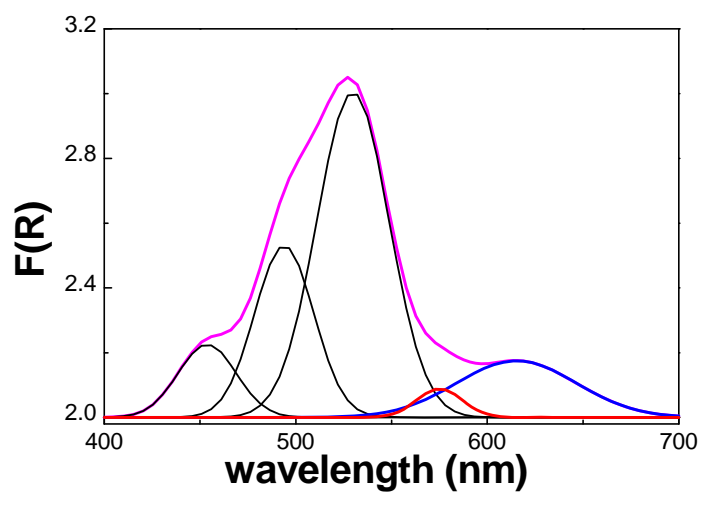

Fig. (12). Diffuse reflectance spectrum of a sample with 4.10 theoretical surface layers of $\left[\mathrm{Co}\left(\mathrm{H}_{2} \mathrm{O}\right)_{6}\right]^{2+}$.

One may conceive the surface precipitation as an increasing tendency for surface polymerization of the deposited cobalt species resulting to tri-dimensional clusters of $\mathrm{Co}(\mathrm{OH})_{2}$ inside the interface. The size of these clusters is limited by the size of the interface (nearly about $1-5 \mathrm{~nm}$ ). Taking into account that these clusters are the precursors of the Co nanoparticles formed after drying and activation of the impregnated solids, one may explain the relatively small size of these nano-particles obtained following equilibrium deposition filtration or homogeneous deposition precipitation [4043], two techniques which favor surface precipitation. In contrast, the application of the conventional dry impregnation technique, which favors solution precipitation, usually results to relatively large Co nano-particles.

The deposition of the Co(II) through surface precipitation at surface $\mathrm{Co}$ (II) concentration higher than 2.70 theoretical surface layers of $\left[\mathrm{Co}\left(\mathrm{H}_{2} \mathrm{O}\right)_{6}\right]^{2+}$ is also reflected in the potentiometric mass titration curves [36] illustrated in Fig. (13).

Concerning the impregnating solution one may observe an abrupt increase of $\mathrm{pH}$ which level of at about 8 . The horizontal part of the curve corresponds to the solution precipitation of the $\mathrm{Co}(\mathrm{OH})_{2}$. In contrast, the horizontal part of the curve of the impregnating suspension appears at about $\mathrm{pH} 7$, which precludes solution precipitation. This is compatible with the surface precipitation inferred by the isotherm. The origin of the surface precipitation is mainly the quite different values for $\mathrm{pH}$ and $\mathrm{Co}(\mathrm{II})$ concentration inside the interface with respect to the corresponding ones in the bulk solution upon impregnation.

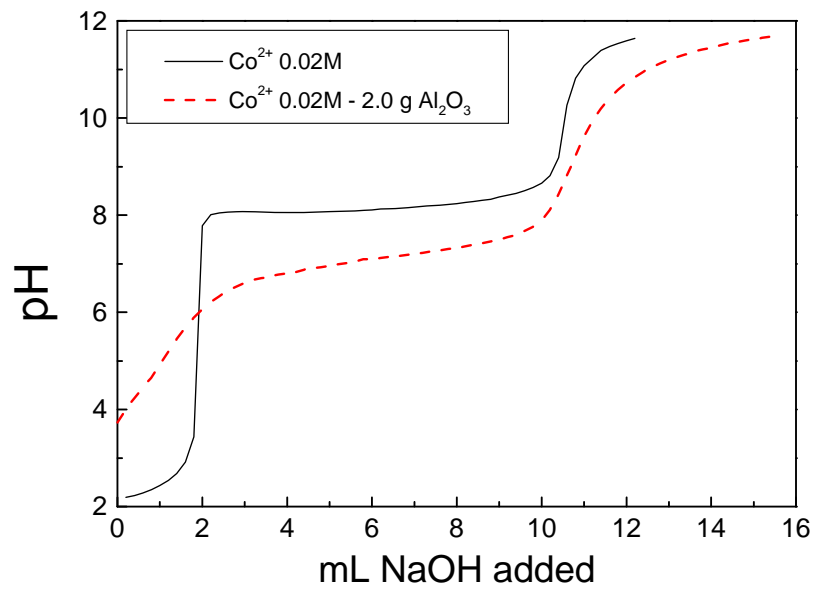

Fig. (13). Variation of $\mathrm{pH}$ of the impregnating solution (solid line) and the impregnating suspension (dot line) with the volume of the added $\mathrm{NaOH}$ solution $(0.25 \mathrm{M})$. The concentration of the cobalt solution and the mass of the support are indicated.

From all the above is clearly shown that the change of the $\mathrm{Co}$ (II) surface concentration, easily obtained by adjusting the impregnation parameters, affects the cobalt species formed at at the " $\gamma$-alumina/aquatic solution" interface. This is probably due to the accumulation of cobalt species in the interface region changing the physicochemical parameters of the double layer, the known tendency of dimerization of cobalt ions in the " $\gamma$-alumina/aquatic solution" interface, and the promotion of the adsorption by the cobalt (II) species already adsorbed.

The evolution of the surface cobalt species with the Co(II) surface concentration is illustrated in Table 2.

\section{CONCLUSION}

We may conclude that the change of the Co(II) surface concentration affects the cobalt species formed at the " $\gamma$-alumina/aquatic solution" interface. More specifically, the formation of mononuclear/mono-substituted inner sphere $\mathrm{Co}$ (II) complexes occurs at extremely low Co(II) surface concentration. A mixed surface state involving mononuclear/ mono-substituted and binuclear/bi-substituted Co(II) complexes is formed at relatively low $\mathrm{Co}$ (II) surface concentration. Only binuclear/bi-substituted Co(II) complexes are formed at intermediate $\mathrm{Co}(\mathrm{II})$ surface concentration. Finally, oligonuclear inner sphere $\mathrm{Co}$ (II) species are formed at relatively high $\mathrm{Co}(\mathrm{II})$ surface concentration, in addition to the bi- 
nuclear ones. The above species contain a range of surface $\mathrm{Co}$ (II) concentration extending from zero to 2.7 theoretical surface layers of $\left[\mathrm{Co}\left(\mathrm{H}_{2} \mathrm{O}\right)_{6}\right]^{2+}$. The formation of $\mathrm{Co}(\mathrm{II})$ surface precipitate starts above these theoretical surface layers. The above indicate that we are able to control the surface $\mathrm{Co}(\mathrm{II})$ concentration and thus the development of effective $\mathrm{Co} / \gamma$-alumina catalysts.

\section{CONFLICT OF INTEREST}

The authors confirm that this article content has no conflict of interest.

\section{ACKNOWLEDGEMENTS}

Declared none.

\section{REFERENCES}

[1] Ewbank, J.L.; Kovarik, L.; Kenvina Ch.C.; Sievers, C. Effect of preparation methods on the performanceof $\mathrm{Co} / \mathrm{Al} 2 \mathrm{O} 3$ catalysts for dry reforming of methane. Green Chem., 2014, 16, 885-896.

[2] Liu, C.; Li, J.; Zhang, Y.; Chen, S.; Zhu, J.; Liew, K. FischerTropsch synthesis over cobalt catalysts supported on nanostructured alumina with various morphologies. J. Mol. Catal. A., 2012, 363-364, 335-342.

[3] Minnermann, M.; Grossmann, H.K.; Pokhrel, S.; Thiel, K.; Hagelin-Weaver, H.; Bäumer, M.; Mädler, L. Double flame spray pyrolysis as a novel technique to synthesize alumina-supported cobalt Fischer-Tropsch catalysts. Catal. Today, 2013, 214, 90-99.

[4] Sadeqzadeh, M.; Karaca, H.; Safonova, O.V.; Fongarland, P.; Chambrey, S.; Roussel, P.; Griboval-Constant, A.; Lacroix, M.; Curulla-Ferré, D.; Luck, F.; Khodakov, A.Y. Identification of the active species in the working alumina-supported cobalt catalyst under various conditions of Fischer-Tropsch synthesis. Catal. Today, 2011, 164, 62-67.

[5] Rane, S.; Borg, Ø.; Rytter, E.; Holmen, A. Relation between hydrocarbon selectivity and cobalt particle size for alumina supported cobalt Fischer-Tropsch catalysts. Appl. Catal. A., 2012, 437-438, 10-17.

[6] Medina, C.; García, R.; Reyes, P.; Fierro, J.L.G.; Escalona, N. Fischer Tropsch synthesis from a simulated biosyngas feed over $\mathrm{Co}(x) / \mathrm{SiO}_{2}$ catalysts: Effect of Co-loading. Appl. Catal. A., 2010, 373, 71-75.

[7] Cornaro, U.; Rossini, S.; Montanari, T.; Finocchio, E.; Busca, G. $\mathrm{K}$-doping of $\mathrm{Co} / \mathrm{Al}_{2} \mathrm{O}_{3}$ low temperature Fischer-Tropsch catalysts. Catal. Today, 2012, 197, 101-108.

[8] San José-Alonso, D.; Illán-Gómez, M.J.; Román-Martínez, M.C. Low metal content $\mathrm{Co}$ and $\mathrm{Ni}$ alumina supported catalysts for the $\mathrm{CO}_{2}$ reforming of methane. Intern. J. Hydrogen Energy, 2013, 38, 2230-2239.

[9] Ma, W.; Jacobs, G.; Sparks, D.E.; Gnanamani, M.K.; Ramana Rao Pendyala, V.; Yen, C.H.; Klettlinger, J.L.S.; Tomsik, T.M.; Davis, B.H. Fischer-Tropsch synthesis: support and cobalt cluster size effects on kinetics over $\mathrm{Co} / \mathrm{Al}_{2} \mathrm{O}_{3}$ and $\mathrm{Co} / \mathrm{SiO}_{2}$ catalysts. Fuel, 2011, 90, 756-765.

[10] Vogelaar, B.M.; van Langeveld, A.D.; Kooyman, P.J.; Lok, C.M.; Bonné, R.L.C.; Moulijn, J.A. Stability of metal nanoparticles formed during reduction of alumina supported nickel and cobalt catalysts. Catal. Today, 2011, 163, 20-26.

[11] Chamoun, R.; Demirci, U.B.; Cornu, D.; Zaatar, Y.; Khoury, A.; Khoury, R.; Miele, P. Cobalt-supported alumina as catalytic film prepared by electrophoretic deposition for hydrogen release applications. Appl. Surf. Sci., 2010, 256, 7684-7691.

[12] Kollár, M.; De Stefanis, A.; Solt, H.E.; Mihályi, M.R.; Valyon, J.; Tomlinson, A.A.G. The mechanism of the Fischer-Tropsch reaction over supported cobalt catalysts. J. Mol. Catal. A., 2010, $333,37-45$.

[13] de la Osa, A.R.; De Lucas, A.; Romero, A.; Valverde, J.L.; Sánchez, P. Influence of the catalytic support on the industrial Fischer-Tropsch synthetic diesel production. Catal. Today, 2011, $176,298-302$
[14] Bourikas, K.; Kordulis, Ch.; Lycourghiotis, A. The role of the solid-liquid interface in the preparation of supported catalysts. Catal. Rev., 2006, 48, 363-444.

[15] Ataloglou, T.; Vakros, J.; Bourikas, K.; Fountzoula, C.; Kordulis, Ch.; Lycourghiotis A. Influence of the preparation method on the structure - activity of cobalt oxide catalysts supported on alumina for complete benzene oxidation. Appl. Catal. B., 2005, 57, 299312 .

[16] Ataloglou, T.; Fountzoula, C.; Bourikas, K.; Vakros, J.; Lycourghiotis A.; Kordulis, Ch. Cobalt oxide/ $\gamma$ - alumina catalysts prepared by Equilibrium Deposition Filtration: the influence of the initial cobalt concentration on the structure of the oxide phase and on its activity for complete benzene oxidation. Appl. Catal. A., 2005, 288, 1-9.

[17] Sarellas, A.; Niakolas, D.; Bourikas, K.; Vakros, J.; Kordulis, Ch. The influence of the preparation method and the Co loading on the structure and activity of cobalt oxide/ $\gamma$-alumina catalysts for NO reduction by propene. J. Colloid Interf. Sci., 2006, 295, 165-72.

[18] Vordonis, L.; Spanos, N.; Koutsoukos, P.G.; Lycourghiotis, A. The mechanism of adsorption of $\mathrm{Co}^{2+}$ and $\mathrm{Ni}^{2+}$ ions on the pure and fluorinated $\gamma$-aluminas/electrolyte solution. Langmuir., 1992, 8, 1736-1743

[19] Spanos, N;. Lycourghiotis, A. Mechanism of deposition of $\mathrm{Co}^{2+}$ and $\mathrm{Ni}^{2+}$ ions on the interface between pure and $\mathrm{F}^{-}$doped $\gamma$ - alumina and the impregnating solution. J. Chem. Soc. Faraday Trans., 1993, 89, 4101-4107.

[20] Vakros, J.; Kordulis, Ch.; Lycourghiotis, A. Cobalt oxide supported $\gamma$-alumina catalyst with very high active surface area prepared by Equilibrium Deposition Filtration. Langmuir., 2002, 18, 417-22.

[21] Bourikas, K.; Kordulis, Ch.; Vakros, J.; Lycourghiotis, A Adsorption of cobalt species on the interface between aqueous solution and metal oxides used for the preparation of supported catalysts: a critical review. Adv. Colloid Interface Sci., 2004, 110, 97-120.

[22] Vakros, J.; Bourikas, K.; Perlepes, S.; Kordulis, Ch.; Lycourghiotis, A. The adsorption of the cobalt ions on the"electrolytic solution/ $\gamma$-alumina" interface studied by Diffuse Reflectance Spectroscopy (DRS). Langmuir., 2004, 20, 10542-10550.

[23] Ataloglou, T.; Bourikas, K.; Vakros, J.; Kordulis, Ch.; Lycourghiotis A. Kinetics of adsorption of the cobalt ions on the "electrolytic solution/ $\gamma$-alumina" interface. J. Phys. Chem. B. 2005, 109, 4599-4607.

[24] Petsi, T.; Panagiotou, G.D.; Bourikas, K.; Kordulis, Ch.; Voyiatzis, G.A.; Lycourghiotis, A. Interfacial impregnation chemistry in the synthesis of chromium catalysts supported on titania. Chem. Cat. Chem., 2011, 3, 1072-1082.

[25] Bourikas, K.; Stavropoulos, J.; Garoufalis, C.S.; Kordulis, Ch.; Petsi, T.; Lycourghiotis, A. Interfacial impregnation chemistry in the synthesis of nickel catalysts supported on titania. Chemistry - $A$ Eur. J., 2011, 17, 1201-1213.

[26] Panagiotou, G.D.; Petsi, T.; Bourikas, K.; Kalampounias, A.G.; Boghosian, S.; Kordulis, C.; Lycourghiotis, A. Interfacial impregnation chemistry in the synthesis of molybdenum catalysts supported on titania. J. Phys. Chem. C., 2010, 114, 11868-11879.

[27] Petsi, T.; Panagiotou, G.D.; Garoufalis, C.S.; Kordulis, C.; Stathi, P.; Deligiannakis, Y.; Lycourghiotis, A.; Bourikas, K. Interfacial impregnation chemistry in the synthesis of cobalt catalysts supported on titania. Chemistry - A Eur. J., 15 (2009) 13090-104.

[28] Panagiotou, G.D.; Petsi, T.; Bourikas, K.; Kordulis, C.; Lycourghiotis, A. The interfacial chemistry of the impregnation step involved in the preparation of tungsten (VI) supported titania catalysts. J. Catal., 2009, 262, 266-279.

[29] Panagiotou, G.D.; Petsi, T.; Bourikas, K.; Garoufalis, C.S.; Tsevis, A.; Spanos, N.; Kordulis, Ch.; Lycourghiotis, A. Mapping the surface (hydr)oxo-groups of titanium oxide and its interface with an aqueous solution. Adv. Colloid Interface Sci., 2008, 142, 20-42.

[30] Bourikas, K.; Vakros, J.; Fountzoula, Ch.; Kordulis, Ch.; Lycourghiotis A. Interface science for optimizing the size of oxidic nanoparticles in supported catalysts. Catal. Today, 2007, 128, 138-144.

[31] Vakros, J.; Papadopoulou, Ch.; Lycourghiotis, A.; Kordulis, Ch. Hydrodesulfurization catalyst bodies with various $\mathrm{Co}$ and $\mathrm{Mo}$ profiles Appl. Catal. A., 2011, 399, 211-220.

[32] Vakros, J.; Lycourghiotis, A.; Voyiatzis, G.A.; Siokou, A.; Kordulis, Ch. $\mathrm{CoMo} / \mathrm{Al}_{2} \mathrm{O}_{3}-\mathrm{SiO}_{2}$ catalysts prepared by coequilibrium deposition filtration: characterization and catalytic 
behavior for the hydrodesulphurization of thiophene. App. Catal. B., 2010, 96, 496-507.

[33] Bourikas, K.; Hiemstra, T.; Van Riemsdijk, W.H. Adsorption of molybdate monomers and polymers on titania with a multisite approach. J. Phys. Chem. B, 2001, 105, 2393-2403.

[34] Samdell, E.B.; Colorimetric determination of traces of metals; Interscience: New York, 1950, p. 274.

[35] Vakros, J.; Kordulis, Ch.; Lycourghiotis, A. Potentiometric mass titrations: a quick scan for determining the point of zero charge. Chem. Commun., 2002, 1980-1981.

[36] Bourikas, K.; Vakros, J.; Kordulis, Ch.; Lycourghiotis, A. Potentiometric mass titrations: experimental and theoretical establishment of a new technique for determining the point of zero charge (PZC) of metal (hydr)oxides. J. Phys. Chem. B, 2003, 107, 9441-9451.

[37] Gustafsson, J.P. Visual MINTEQ ver. 2.40, Department of Land and Water Resources Engineering, Royal Institute of Technology, Stockholm, 2005.

[38] Arrouvel, C.; Digne, M.; Breysse, M.; Toulhoat, H. ; Raybaud, P. Effects of morphology on surface hydroxyl concentration: a DFT comparison of anatase- $\mathrm{TiO}_{2}$ and $\gamma$-alumina catalytic supports. J. Catal., 2004, 222, 152-166.
[39] Digne, M.; Sautet, P.; Raybaud, P.; Euzen, P.; Toulhoat, H. Hydroxyl groups on $\gamma$-alumina surfaces: a DFT study. J. Catal. 2002, 211, 1-5.

[40] Bitter, J.H.; van der Lee, M.K.; Slotboom, A.G.T.; van Dillen, A.J.; de Jong, K.P. Synthesis of highly loaded highly dispersed nickel on carbon nanofibers by homogeneous deposition-precipitation. Catal. Lett., 2003, 89, 139-142.

[41] Toebes, M.L.; van der Lee, M.K.; Tang, L.M.; Huis in't Veld, M.H.; Bitter, J.H.; van Dillen, A.J.; de Jong, K.P. Preparation of carbon nanofiber supported platinum and ruthenium catalysts: comparison of ion adsorption and homogeneous deposition precipitation. J. Phys. Chem. B, 2004, 108, 11611-11619.

[42] Patil, N.S.; Uphade, B.S.; McCulloh, D.G.; Bhargava, S.K.; Choudhary, V.R. Styrene epoxidation over gold supported on different transition metal oxides prepared by homogeneous deposition-precipitation. Catal. Commun., 2004, 5, 681-685.

[43] Bezemer, G.L.; Radstake, P.B.; Koot, V.; van Dillen, A.J.; Geus, J.W.; de Jong, K. P. Preparation of Fischer-Tropsch cobalt catalysts supported on carbon nanofibers and silica using homogeneous deposition-precipitation. J. Catal., 2006, 237, 291-302.

(C) Vakros et al.; Licensee Bentham Open.

This is an open access article licensed under the terms of the Creative Commons Attribution Non-Commercial License (http://creativecommons.org/licenses/ by-nc/3.0/) which permits unrestricted, non-commercial use, distribution and reproduction in any medium, provided the work is properly cited. 